\title{
Innovation in Teaching-Learning Process: An Experiment of Srinivas University
}

\author{
K.V. M. Varambally ${ }^{1}$, Sujaya H. ${ }^{2} \&$ P. S. Aithal ${ }^{3}$ \\ ${ }^{1}$ Research Professor, College of Management \& Commerce, Srinivas University, \\ Mangalore- 575 001, India \\ E-mail: kvmvarampally@gmail.com \\ ${ }^{2}$ Research Scholar, College of Management \& Commerce, Srinivas University, Mangalore, \\ India \\ ${ }^{3}$ Professor, College of Management \& Commerce, Srinivas University, Mangalore - 575001 \\ ORCID: https://orcid.org/0000-0002-4691-8736; Email: psaithal@gamil.com
}

Area of the Paper: Business Management.

Type of the Paper: Research Paper.

Type of Review: Peer Reviewed as per $|\mathrm{C}| \mathrm{O}|\mathrm{P}| \mathrm{E} \mid$ guidance.

Indexed In: OpenAIRE.

DOI: http://doi.org/10.5281/zenodo.3761723.

Google Scholar Citation: IJCSBE.

\section{How to Cite this Paper:}

Varambally, K. V. M., Sujaya, H., \& Aithal, P. S. (2020). Innovation in Teaching-Learning Process: An Experiment of Srinivas University. International Journal of Case Studies in Business, IT, and Education (IJCSBE), 4(1), 1-7.

DOI: http://doi.org/10.5281/zenodo.3761723.

International Journal of Case Studies in Business, IT and Education (IJCSBE)

A Refereed International Journal of Srinivas University, India.

(C) With Authors.

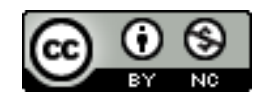

This work is licensed under a Creative Commons AttributionNon-Commercial 4.0 International License subject to proper citation to the publication source of the work.

Disclaimer: The scholarly papers as reviewed and published by the Srinivas Publications (S.P.), India are the views and opinions of their respective authors and are not the views or opinions of the S.P. The S.P. disclaims of any harm or loss caused due to the published content to any party. 


\title{
Innovation in Teaching-Learning Process: An Experiment of Srinivas University
}

\author{
K. V. M. Varambally ${ }^{1}$,Sujaya $H^{2}{ }^{2}$ \& P. S. Aithal $^{3}$ \\ ${ }^{1}$ Research Professor, College of Management \& Commerce, Srinivas University, \\ Mangalore- 575 001, India \\ E-mail: kvmvarampally@gmail.com \\ ${ }^{2}$ Research Scholar, College of Management \& Commerce, Srinivas University, Mangalore, \\ India \\ ${ }^{3}$ Professor, College of Management \& Commerce, Srinivas University, Mangalore - 575001 \\ ORCID: https://orcid.org/0000-0002-4691-8736; Email: psaithal@gamil.com
}

\begin{abstract}
In an education system updation, upgradation, and quality improvement are the necessary factors to maintain fitness in the changing environment. Teaching community needs to upgrade their teaching quality keeping knowledge about the latest happenings in the real world. Individual growth and Institutional growth must grow together. The goal congruence between teachers and educational institutions facilitate for accelerated development. Apart from this the students/aspirants for education need to have knowledge as well as skill to enhance their employability in the market.This paper aims to highlight the innovative experiment of Srinivas University which attempted quality improvement of postgraduate students as well as teaching community in order to maintain its fitness and also enhance its uniqueness among private universities.
\end{abstract}

Keywords: Higher education (HE), HE Innovations, Teaching-learning process, Srinivas university.

\section{INTRODUCTION :}

The purpose of education is not to produce literates or just to impart knowledge among the student population. The preview of education has to incorporate emotional and spiritual intelligence along with the cognitive knowledge base among students. This broad-based education system enables students to build a solid base for their carrier growth and also enables them to grow as responsible and socially acceptable citizens in a country. Educational Institutions especially those impart higher education needs to facilitate for wide education base for the student community. In the wide based education system opportunity must be created for group learning, learning from observations, on the job training, interactive and reflective learning along with the self-learning or classroom learning process.

Bhartruharia well-known poet in the past in his Nithisataka (moral poem) explains that education is the means for total personality development. According to him [1] :

Vidyanamanarasyarupamadhikamprachhannaguptamdhanam

Vidyabhogakariyasassukhakari vidya gurunamguruh

Vidya bandhujanovidesagamanevidya apara devata

vidya rajasupoojitana hidhanamvidyaviheenahpashuh

Bhartruhari views that education develops the personality and charisma of a person, it acts as a hidden treasure. It enables a person to lead a comfortable life. It facilitates for individual success in life. It is like a close relative and in a foreign land, education comes to rescue a person like God. Education brings image and recognition from the ruler, those who are deprived of education is like an animal and do not have any respect in the society. 
A popular saying in Sanskrit known as Subhashita explains the importance of Education as follows :Vidya dadativinayam, Vinayath-yatipatratam, Patratwatdhanamapnoti, Dhanatdharmamtatahsukham

According to the Subhashita Education enables a person to develop kind heartedness. This quality helps to build up his personality with good character. Good personality developed by him helps to earn a livelihood, and from that, he can enjoy his life in a way accepted by society [2]. In other words, education becomes fruitful if it imbibes qualities such as empathy, kindness, good character and acceptable personality.

It has been viewed that for the real development of an economy there is a need for effective interaction between business and education system. The total developmental efforts would become rewarding and impact making if there is provision for effective interaction between education institutions and Business Organisations. (Gosavi 1986) [4]. The interaction process makes the learning active and widens the process of understanding of students. Exposure to external words enables the students to go deeper into the field of knowledge as well as the real problem situations of the external world. In depth understanding of the problem paves the way in providing practical solutions to the prevailing issues.

Experts view that it is the education system which provides the base for human development as well as National Development (Ranganathanda 1984) and Education[5], self-discipline, hard work cooperative work, and the humanistic impulse are the four means by which an underdeveloped country can become a developed nation, education transforms human force into human resource [6]. Therefore, education plays a vital role in the development of a nation.

Management education has been developed as a need based and responsive to the changes in the market environment. Three aspects considered as important in Management education are [3] :

(a) Practical Orientation

(b) Professionalism and

(c) Humane and interpersonal relationships. These qualities help an individual tokeep himself fit and contribute meaningfully in any business sector. Today wecan see the growth of management schools in the country producing over 3 lakhsmanagementgraduates annually.

According to a study conducted by UNICEF in India by 2030, only 47 percent of youth will have adequate skills to pursue their future career. The study reveals that only 19 percent of students have skills in 2019. Even though a large number of graduates come out of universities in India most of them are deprived of skill development. The reason for this is due to inadequate interest among students and non-availability quality education to suit market requirements.

Table 1: Details of the percentage of skilled youth in different countries

\begin{tabular}{|l|c|c|}
\hline \multicolumn{1}{|c|}{ Country } & $\underline{\mathbf{2 0 1 9}(\mathbf{\%})}$ & $\underline{\mathbf{2 0 3 0}(\mathbf{\% )}}$ \\
\hline Sri Lanka & 61 & 68 \\
\hline Bhutan & 47 & 81 \\
\hline Bangladesh & 26 & 55 \\
\hline India & 19 & 47 \\
\hline Nepal & 18 & 40 \\
\hline Pakistan & 18 & 40 \\
\hline Maldives & 16 & 46 \\
\hline
\end{tabular}

Source : Karthik Amai ; Udayavani 15.11.2019 P.6

The UNICEF study shows that the unemployment rate in India is 8.45 percent in 2019 . In the education field in spite of several steps towards quality improvement, they are inadequate enough to fullfill the needs of market conditions. 
Classroom teaching is basically to help the student to enhance their knowledge and thinking ability. Preparation for the purpose of examination does not help to understand the problem prevailing in the external market. Therefore, it is necessary to provide an opportunity to students to expose tothe external world during the course of their study. This helps them to build up their understanding of real world and helps to improve their confidence level as well as a leadership capability. A student with adequate exposure and communication skills is able to learn faster in an organization and contribute meaningfully as per its needs. Inbuilt flexibility in the University system enables out of the box thinking and provides encouragement to students in new approaches and training programmes which helps them in their future endeavour and contributes to their personality development.

\section{OBJECTIVES AND METHODOLOGY:}

The present paper aims to highlight the efforts of Srinivas University in its teaching learning process to enhance the quality of teachers as well as students. Encouragement to faculty in Research and Publications and opportunity to students in experimental learning enable both teachers and students to improve their fitness and prove their worth as per the needs of the market environment. The information has been collected from the official records and students who have undergone the experimental learning process. Faculty members those who are teaching postgraduate programme have been interviewed and their opinion regarding the benefit they obtained from Institutional support towards research and publication.

\section{ABOUT THE UNIVERSITY :}

Srinivas Group of Institutions imparts education in the fields such as Business Management, Engineering, Nursing, medical and paramedical courses. The Group obtained University status in the year 2013 under the Act of University Grants Commission. Since its inception, the University endeavours to provide quality education to students and support faculty members to upgrade their knowledge base through Research and Publication. It has made many innovations in best practices in new course development [7-11], in library services [12], strategic planning [13], and to increase research productivity [14]. Every year the constituent colleges are required to organize National and International Conferences to the user the skills of the teaching fraternity. Organizing such events certainly develop the introduction skills of faculty and also create a conducive environment for Research and Publications.

To support the faculty in Research and Publications, university has appointed senior faculty as Research Professors on a constant basis. These senior faculty group provides necessary guidance and support to faculty members in preparation of research proposal, keep up the quality standard in Research work. They further extend their support to Research Faculty in Research Publications.

Apart from this, the faculty members of various Institutions of Srinivas University are required to organize Conferences and Seminars. Such Institutions as per the guidelines are required to organise two conferences during the academic year. Along with the organization, the university provides incentives in performance appraisal for those faculty present research papers with the conference.

To accelerate the publication work of faculty the University has started Srinivas Publications which Public International Journal of Management and Technology, which hasanimpact factor of 4.764 in 2018.The opinion of teachers pertaining to conducive environment regarding Research and Publication has been given in table 2.

Table 2 : Opinion of Faculty regarding conducive environment related to Research and Publication (in percentage)

\begin{tabular}{|c|l|c|c|c|c|c|}
\hline $\begin{array}{c}\text { SL } \\
\text { No. }\end{array}$ & Factor & $\begin{array}{c}\text { Strongly } \\
\text { Agree }\end{array}$ & Agree & $\begin{array}{c}\text { Neither } \\
\text { Agree or } \\
\text { disagree }\end{array}$ & Disagree & $\begin{array}{c}\text { Strongly } \\
\text { disagree }\end{array}$ \\
\hline & & 5 & 4 & 3 & 2 & 1 \\
\hline 1. & $\begin{array}{l}\text { Created healthy competition } \\
\text { among faculty }\end{array}$ & $23.33 \%$ & $70.00 \%$ & $6.67 \%$ & $0.00 \%$ & $0.00 \%$ \\
\hline 2. & Developed amicable & & & & & \\
\hline
\end{tabular}

K. V. M. Varambally et al, (2020); www.srinivaspublication.com 


\begin{tabular}{|c|l|c|c|c|c|c|}
\hline & relationship among faculty & $16.57 \%$ & $66.66 \%$ & $16.67 \%$ & $0.00 \%$ & $0.00 \%$ \\
\hline 3. & $\begin{array}{l}\text { Improvements in } \\
\text { inquisitiveness }\end{array}$ & $16.57 \%$ & $66.66 \%$ & $16.67 \%$ & $0.00 \%$ & $0.00 \%$ \\
\hline 4. & $\begin{array}{l}\text { Adequate support in Research } \\
\text { and Publication }\end{array}$ & $57.00 \%$ & $37.00 \%$ & $6.67 \%$ & $0.00 \%$ & $0.00 \%$ \\
\hline 5. & $\begin{array}{l}\text { Encouragement to organize } \\
\text { events /activities }\end{array}$ & $43.00 \%$ & $53.00 \%$ & $3.33 \%$ & $0.00 \%$ & $0.00 \%$ \\
\hline
\end{tabular}

It is evident from the Table 2 that the conducive environment created by the University system enabled most of the faculty - to improve their style of work. Healthy competition, support from the University for Research and Publication encouragement to organise events and academic activities motivated them to excel and show better performance. Amicable relationship among faculty helped them to organise seminars and conferences and facilitate for their academic leadership and better learning.

\section{STUDENTS EXPERIMENTAL LEARNING :}

Students of Management are allowed to take up part time jobs in small business establishments. University identifies the small business units for the job. Those who accept the job are required to work as per the guidelines of business units and also as per the instructions given by faculty members. The experience of students as employees is evaluated by the faculty of the University.The part time jobs available to students not only provides financial support but also develops the confidence level of students to obtain meaningful employment after their graduation.

Apart from this University provided opportunity to senior students to train juniors in communication and interactive learning process. Since this exercise is also a part of internal assessment students take up the task more seriously and enhance their interactive skills. The opinion of students who have undergone experimental learning has been given in table.

TABLE 3 :Opinion of Students regarding Experimental Learning Process (in percentage)

\begin{tabular}{|c|l|c|c|c|c|c|}
\hline SL No. & $\begin{array}{l}\text { Tick one response for each of } \\
\text { the following items }\end{array}$ & $\begin{array}{l}\text { Strongly } \\
\text { Agree }\end{array}$ & Agree & $\begin{array}{c}\text { Neither } \\
\text { Agree or } \\
\text { Disagree }\end{array}$ & Disagree & $\begin{array}{c}\text { Strongly } \\
\text { Disagree }\end{array}$ \\
\cline { 3 - 7 } & & 5 & 4 & 3 & 2 & 1 \\
\hline 1. & $\begin{array}{l}\text { Improvement in confidence } \\
\text { level }\end{array}$ & $70.00 \%$ & $40.00 \%$ & $3.33 \%$ & $0.00 \%$ & $0.00 \%$ \\
\hline 2. & $\begin{array}{l}\text { Development of interactive } \\
\text { skill }\end{array}$ & $57.00 \%$ & $37.00 \%$ & $6.67 \%$ & $0.00 \%$ & $0.00 \%$ \\
\hline 3. & $\begin{array}{l}\text { Improvements in leadership } \\
\text { ability in the planning and }\end{array}$ & $53.00 \%$ & $37.00 \%$ & $6.67 \%$ & $6.67 \%$ & $0.00 \%$ \\
\hline 4. & $\begin{array}{l}\text { Helped in } \\
\text { organisation process }\end{array}$ & $43.00 \%$ & $47.00 \%$ & $6.67 \%$ & $0.00 \%$ & $0.00 \%$ \\
\hline 5. & Helped in overall personality & $57.00 \%$ & $33.00 \%$ & $3.33 \%$ & $3.33 \%$ & $0.00 \%$ \\
\hline
\end{tabular}

Table 3provides the details of the opinion of students pertaining to the benefit of experimental learning. Most of the respondents strongly felt that the experimental learning enabled them to improve their confidence level. The interactive skills enhanced their leadership quality and improve their overall personality. 


\section{DISCUSSIONS AND SUGGESTIONS :}

The innovative experiment in teaching-learning process of Srinivas University reveals that both the teaching community and students benefit from the new approach and both the group have given positive remarks about this. The new experiments enabled the teachers to build up their quality standards through more publications and academic interactions at conferences. The academic base of the teachers has been strengthened through the competitive environment and given enthusiasm to them to engage themselves meaningfully in teaching research and publication. Moreover, the amicable relationship among the faculty has strengthened further which facilitates cooperation and mutual help.

The experiment enhanced the employability of students. Their confidence level with interactive ability helped them to develop a positive mindset and lay a foundation for their future career. It assured to bring down the gap between the expectations of the corporateworld and students' capability. Enhancement with the learning process enabled themselves to become the best fit in the job market.

\section{CONCLUSION :}

The new experiment of Srinivas University provided inspirational support both for faculty and students to enhance their quality of learning and enable them to improve their total personality. Teaching faculty are motivated in the area of Research and Publication along with their routine academic responsibility. The competitive environment paved the way for continuous engagement and positive interaction. Their plan for academic advancement keeps them busy in their futuristic approach with a meaningful contribution. Students with a new approach enhanced their personality and fitness which helped them to face challenges with a competitive environment.

\section{REFERENCES :}

[1] https://sanskritpearls.blogspot.com/2010/03/march-27th.html, Referred on 05/03/2010.

[2] Ashi’s Gupta (2010). Indian Entrepreneur Actions New Age International (P) Limited New Delhi.

[3] Vasant Desai (2001). Dynamics of Experimental development and Management Himalaya Publishing House, New Delhi.

[4] Gosavi M.S. (1986). Business Education and Entrepreneurship Development Gokhale Education Society.

[5] Swami Ranganathanda: Human Values in Management Punjab National Bank New Delhi 1984.

[6] Nagarajan K. (2011). Indian Ethos and Values : New Age International (P) Ltd. New Delhi.

[7] Aithal, P. S. \& Suresh Kumar,P.M. (2016). Innovations in Private Universities : A Case of Srinivas University. International Journal of Management, IT and Engineering (IJMIE), 6(1), 250-264. DOI:http://doi.org/10.5281/zenodo.161151.

[8] Aithal, P. S. \& Jeevan Pinto, (2016). Innovations in Higher Education - A new model implemented in MCA degree programme of Srinivas University. International Journal of Scientific Research and Modern Education (IJSRME), 1(1), 275-289. DOI:http://doi.org/10.5281/zenodo.161107.

[9] Aithal, P. S. and Sonia D. N. (2016). Hitting Two Birds with One Stone : Srinivas University B.Com. Model in Corporate Auditing.International Journal of Scientific Research and Modern Education (IJSRME), 1(1), 853-869. DOI:http://doi.org/10.5281/zenodo.154602.

[10] Aithal, P. S., A. Srinivas Rao, \& Suresh Kumar, P.M. (2015). How Innovations and Best Practices can Transform Higher Education Institutions : A case study of SIMS. International Journal of Management (IJM), 6(2), 83 - 98. DOI: http://doi.org/10.5281/zenodo.61594.

[11] Aithal, P. S. (2015). Comparative Study on MBA Programmes in Private \& Public Universities A case study of MBA programme plan of Srinivas University. International Journal of Management Sciences and Business Research (IJMSBR), 4(12), 106-122.DOI :http://doi.org/10.5281/zenodo.163884. 
[12] Aithal, P. S., \&Harischandra, P. (2015). Quality Enhancement in Higher Education Institutions through Best Practices in Library: A Case of SIMS.International Journal of Management, IT and Engineering (IJMIE), 5(7), 489-505, DOI: http://doi.org/10.5281/zenodo.268518.

[13] Srinivas Rao, A., Suresh Kumar, \& Aithal, P. S. (2015). Strategic Planning in Higher Education Institutions : A Case Study of SIMS - VISION 2025. International Journal of Educational Science and Research, 5(2), 29-42. DOI: http://doi.org/10.5281/zenodo.61589.

[14] Aithal, P. S. (2016). How to Increase Research Productivity in Higher Educational Institutions SIMS Model. International Journal of Scientific Research and Modern Education (IJSRME), 1(1), 447-458. DOI :http://doi.org/10.5281/zenodo.161037. 